\title{
O ESTADO DE DIREITO ENTRE O ATIVISMO JUDICIAL E A VONTADE DE PODER: UMA CRÍTICA FILOSÓFICA À INFLUÊNCIA DECISIONISTA NA MAGISTRATURA, MEDIANTE UMA REFLEXÃO EM NIETZSCHE E SCHMITT
} THE RULE OF LAW BETWEEN JUDICIAL ACTIVISM AND THE POWER WILL: A PHILOSOPHICAL CRITICISM TO DECISIONIST INFLUENCE IN MAGISTRATING, BY A REFLECTION IN NIETZSCHE AND SCHMITT

Fernando Antonio Alves*

RESUMO

Em tempos de crise política, social e econômica, e diante das múltiplas críticas estabelecidas na comunidade jurídica acerca da qualidade das decisões judiciais e de certa judicialização da política, este estudo procura buscar no conceito de vontade de poder alguns mecanismos interpretativos acerca do decisionismo. Tal estudo é formulado não somente no âmbito do constitucionalismo, mas sobretudo por meio da filosofia política, com amparo na pesquisa bibliográfica, a fim de produzir uma reflexão filosófica acerca do decisionismo, impulsionado por uma vontade de poder, ao estabelecer os contornos iniciais ou mesmo o desenvolvimento de um ativismo no aparato judicial brasileiro. Desta forma, observa-se até que ponto o movimento iniciado em setores da magistratura nacional não se configura como afirmação dessa vontade enquanto uma vontade de decisão, bem como no debate protagonizado pelos juízes, estes, paulatinamente, vêm ocupando o espaço outrora relegado aos legisladores.

Palavras-chave: vontade de poder; ativismo judicial; decisionismo; justiça brasileira.

\section{ABSTRACT}

In a time of political, social and economic crisis, and in front of the multiple critiques established in the legal community about the quality of judicial decisions and a certain judicialization of politics, this study proposes searching in the concept of will to power some interpretative mechanisms about decisionism. This study is formulated not only in the context of constitutionalism, but above all through political philosophy, using bibliographic research, and through philosophical reflection, we shall attempt to discuss the extent to which such decisionism, driven by a will to power, establishes the contours or even the development of an activism in the Brazilian judicial apparatus. In this way, it is observed to what extent the movement initiated in sectors of the national judiciary does not introduce as an affirmation of this will as a decision-making, as well as in the debate carried out by the judges, these have gradually occupied the space formerly relegated to legislators.

Keywords: will power; judicial activism; decisionism; brazilian courts.

\footnotetext{
* Doutor em Direito pela Universidade do Vale do Rio dos Sinos (UNISINOS/RS). Mestre em Ciências Sociais pela Pontifícia Universidade Católica de São Paulo (PUC/SP). Especialista em Direito Penal Econômico Europeu pela Universidade de Coimbra, Portugal. proffernando71@gmail.com
} 


\section{SUMÁRIO}

\section{INTRODUÇÃO; 1 VONTADE DE PODER EM NIETZSCHE: UM CONCEITO PARA O ESTADO DE DIREITO ONDE SE JULGA CONFORME O DESEJO E NÃO CONFORME A MORAL; 2 A VONTADE NA TEOLOGIA POLÍTICA DE SCHMITT; 3 OS JUIIZES-LEGISLADORES EM TEMPOS DE EXERCÍCIO DE UMA VONTADE DE DECISÃO; CONCLUSÃO.}

\section{- INTRODUÇÃO}

O sistema político e o sistema jurídico brasileiro passam por um momento em que não há como um observador de segunda ordem não se deparar com a necessidade da reflexão, e até mesmo da crítica filosófica ao aparato judicial. Entre idas e voltas das decisões dos tribunais, é de se notar no que tange ao processamento de atores políticos da cena democrática, certa flexibilidade interpretativa do Supremo Tribunal Federal, acerca da aplicabilidade de princípios como a presunção da inocência, dignidade humana ou mesmo concepções jurídicas sobre conceitos filosóficos bastante desenvolvidos pela razão prática, tais como o de liberdade e autonomia individual ou coletiva.

Causa espécie observar que, no âmbito das decisões proferidas por órgãos jurisdicionais, o que se observa na ratio dos julgadores é uma percepção muito mais política do que jurídica dos fatos sociais. Nos últimos anos avolumam-se processos judiciais com extensa visibilidade midiática, diretamente proporcional ao intenso debate promovido na comunidade jurídica acerca de que até ponto as decisões decorrentes dessas lides afetam ou não a estabilidade da ordem normativa, ou mesmo abalam a credibilidade de um pretenso Estado Democrático de Direito brasileiro. É objetivo deste breve estudo não catalogar exaustivamente tais decisões, mas sim analisar até que ponto são possíveis de observação traços que delineiam o exercício de uma vontade, por detrás desses julgamentos. Vontade que leva a decisionismos, que, por sua vez, podem conduzir a um horizonte crescente de mobilização judicial, que se traduz por muitas vezes na propagação de um mero ativismo por parte de um corpo de magistrados, identificados não apenas como agentes políticos no marco constitucionais, mas sim como genuínos atores a assumir o protagonismo antes dado a outros personagens nas correntes operações sociais desenvolvidas no âmbito do sistema político. Nesse sentido, o conceito de vontade de poder e a própria definição do decisionismo e a concepção do ativismo que se desenvolve no país é de destacada relevância, a fim de se iniciar um profícuo e necessário debate filosófico. Nesse sentido, por meio da pesquisa bibliográfica, buscou-se estabelecer uma investigação teórica acerca dos conceitos de vontade e decisão encontrados tanto no pensamento de Friedrich Nietzsche quanto em Carl Schmitt, o que, doravante, será a tarefa metodológica deste breve e inicial estudo. 
O Estado de Direito entre o ativismo judicial e a vontade de poder: uma crítica filosófica à influência decisionista na magistratura, mediante uma reflexão em Nietzsche e Schmitt

\section{VONTADE DE PODER EM NIETZSCHE: UM CONCEITO PARA O ESTADO DE DIREITO ONDE SE JULGA CONFORME O DESEJO E NÃO CONFORME A MORAL}

No decorrer de sua obra, Nietzsche apresenta vários conceitos do que ele define como vontade, já nos seus últimos anos de vida, período que coincide com sua maturidade intelectual e mais aguda percepção de alguns objetos de sua crítica filosófica, aparece dentre eles a vontade de poder na crítica da moral. Na maior parte destes textos, que após sua morte recolheram-se fragmentos, o pensador alemão referia-se a diversas vontades de poder: no conhecimento, na natureza, como sociedade e indivíduo e como arte.

Para uma reflexão sobre o Estado e o Direito, é necessário compreender, preliminarmente que, para Nietzsche ${ }^{1}$, conceitos como Estado moderno e dignidade do homem fundada na valorização do trabalho, típicos do pensamento liberal, pouco importância tinham, uma vez que o modelo de sociedade desse filósofo estava concentrado no ideal grego. Era entre os gregos que se percebia uma cultura gloriosa, e onde mais se encontrava presente a natureza do poder, pautado na força, na usurpação, ou mesmo na violência. Assim, em sua genealogia, o Direito não teria outro caminho senão fundado na força, num instinto de dominação, em uma vontade de poder, que consistiria, outrossim, numa vontade de subjugar. Portanto, a mesma sociedade florescida de grandes pensadores, oradores e filósofos, formada por homens políticos, também era uma sociedade naturalmente desigual, formada por vencedores e perdedores, numa disputa entre grupos ou categorias sociais e indivíduos. É nessa naturalidade das relações de força, na lógica da usurpação que nasceria, portanto, o Estado ${ }^{2}$.

O Estado é resultante de um ato de força, e é na força que ele se mantém duradouro visto que a guerra faz parte de sua natureza e, para isso, Nietzsche faz alusão a casta dos soldados, demonstrando que, na sua visão, as castas militares revelavam de forma mais evidente a essência do Estado, uma vez que, por meio do instinto guerreiro, seria possível ver a imagem do modelo originário do Estado ${ }^{3}$. A caótica massa de indivíduos seria agora dividida em ordens militares, onde uma classe guerreira subjugaria uma classe dos escravos. É na sua crítica ao modelo de Estado da sociedade liberal-burguesa que Nietzsche invoca o restauracionismo da velha ordem monárquica, ao estender seu dedo acusador aos responsáveis pelo lluminismo e pela Revolução Francesa. Os homens de negócio da sociedade burguesa haveriam desvirtuado o instinto guerreiro do Estado, transformando-o no instinto das finanças e o aparelho do Estado, por sua vez, teria sido convertido para funcionar como um mero meio de enriquecimento dos mais prósperos economicamente.

\footnotetext{
${ }^{1}$ NIETZSCHE, Friedrich Wilhelm. Escritos sobre o direito. Rio de Janeiro: PUC; São Paulo: Loyola, 2009, p. 60.

${ }^{2}$ Curioso observar que na sua teoria do Estado, Nietzsche se propõe a rever alguns conceitos filosóficos trazidos com o desenvolvimento da ciência política, tais como o de contrato social, sendo bastante enfático ao afirmar que a origem beligerante do Estado é um dos fatores encontrados em sua natureza como elemento de expansão do seu desenvolvimento: “(...) o Estado, como dissemos, não é outra coisa senão este punho de ferro que obriga pela violência a sociedade a se desenvolver. Enquanto não há Estado, no bellum ommia contra omnes do estado de natureza, a sociedade não pode absolutamente lançar as bases de uma fundação maior, que se estendesse para além dos limites da família". NIETZCHE, ibidem, p. 62.

${ }^{3}$ NIETZCHE, Escritos sobre o direito, Op. cit., p. 65.
} 
Nietzsche resgata a cidade ideal de Platão, ao reviver a ideia de "gênio", extraído da sabedoria e da ciência e colocado agora na condição de gênio militar do Estado. É o homem rendido a esse gênio guerreiro, sem direitos e sem deveres, com o único propósito de lhe servir como instrumento, que interessa ao filósofo. Nietzsche encontra, então, além da moralidade, além do bem e do mal, uma estética estatal que irá redefinir o Direito como instrumento de um Estado forte, ideal, que se vale da guerra não para infligir qualquer mal além daquele já sofrido por quem guerreia. Para o filósofo germânico, acerca da guerra, "ela só é condenável quando não é consequência de uma necessidade." ${ }^{4}$

Se for compreendido o Estado de Direito não como como uma entidade mantenedora da moral, mas sim como seu oposto, poderá se verificar que tanto o ente estatal quanto as normas que dele ser originam são elaboradas não para satisfazer desígnios morais, mas sim para realizar uma vontade que está acima dessa moral. Nietzsche era um profundo crítico da moralidade kantiana e do imperativo categórico, vez que discordava de seu principal pressuposto, que pode ser encontrado tanto em Kant quanto em Schopenhauer: a liberdade inteligível $^{5}$. Uma liberdade resultante de uma escolha, fundada por sua vez no sentimento moral de que as ações humanas podem ser boas ou más, dependendo das consequências que elas produzem, e, da aferição de um ser do próprio homem, que pode optar por agir desse ou daquele outro modo, não encontra eco na ética nietzschiana. Nietzsche nega a responsabilidade individual, nega a existência de um livre-arbítrio, onde o homem pode refletir sobre suas ações e assim escolher aquela que lhe produz menos mal-estar. As ações humanas são conduzidas pelo desejo, pela sua disposição natural, instintiva, inata, por um querer e não um saber sobre a conduta. Por isso que Nietzsche afirma: "Ninguém é responsável por suas ações, ninguém é responsável por seu ser; julgar significa ser injusto". ${ }^{6}$

Em termos exemplificativos, à guisa de observação da realidade atual do cenário das decisões judiciais brasileiras, hoje, em tempos de uma magistratura plenamente ativista, é possível observar que muitos julgam não por se basear o ato julgador numa moralidade que oriente suas escolhas decisórias; mas sim simplesmente para exercer a vontade de decidir, uma vez que pode decidir, que quer decidir; até mesmo com a consciência de que ao julgar o que pode ser justo ou injusto, não lhe importa a qualidade moral da sentença, mas sim a força com que é proferida.

A vontade que subjaz ao querer humano, independente de volições morais, é, certamente, a vontade de subjugar o mundo ao próprio desejo ${ }^{7}$. Tal constatação gerará um espectro de discricionariedade, que poderá ser percebido em tempos próximos por meio de recentes e controversas decisões judiciais proferidas num meio jurídico que cultiva, desde os primórdios da ciência jurídica, a tese moderna de que se julga conforme o direito, quando, na verdade, pode-se estar julgando conforme a vontade própria, despida de toda a moralidade associada ao ato de julgar, porque dela não se necessita. A busca do espírito livre é, também, a busca daquele que decide e que pode decidir, livre de qualquer abnegação moral. Nietzsche volta-se para um período pré-moral da humanidade, onde o valor ou desvalor da ação era considerado não em sua origem, mas sim em suas consequências. Desta forma, por exemplo, matar ou não matar não seria considerada uma conduta má pelo simples ato de matar, mas

\footnotetext{
${ }^{4}$ Ibid., p. 71.

${ }^{5}$ GIACOIA JUNIOR, Oswaldo. Nietzche e Kant: uma disputa permanente a respeito da liberdade, autonomia e dever. Rio de Janeiro: Casa da Palavra, 2012, p.149.

${ }^{6}$ Ibid., p. 151.

${ }^{7}$ NIETZSCHE, Friedrich. A vontade de poder. Rio de Janeiro: Contraponto, 2008, p. 183.
} 
O Estado de Direito entre o ativismo judicial e a vontade de poder: uma crítica filosófica à influência decisionista na magistratura, mediante uma reflexão em Nietzsche e Schmitt

sim de acordo com os efeitos de tal ato. No início da dimensão estritamente moral do conhecimento, passou-se a cultivar, segundo o pensador alemão, uma certeza imediata sobre a qualidade das condutas, o que levaria a uma certa ingenuidade moral.

Ora, se a realidade está centrada tão somente no mundo dos desejos e das paixões, onde não se pode cobrar uma culpa, uma responsabilidade moral, por que falar de moralidade e por que não somente decidir, isento de qualquer moralidade, de qualquer baliza na aplicação da lei? A moralidade não repousa na norma, mas sim na tradição, onde a formação da dicotomia bem ou mal das ações humanas tem pouca ou nenhuma relação com um imperativo categórico, mas sim com a submissão desta a uma lei da tradição, que visa a conservação de um povo ou comunidade. ${ }^{8}$

Ao voltar-se para o homem europeu, especificamente o povo alemão, em comparação com outros povos que abraçaram o liberalismo, tais como os ingleses e os franceses, Nietzsche exortava uma peculiar profundidade da alma alemã, que adviria de sua indefinição enquanto povo face a multiplicidade de raças que compunha sua estrutura social, não se restringindo tão somente com os pré-arianos. Tal amálgama será notado como contribuição interessante para a própria visão de sociedade que irá ser desenvolvida no século XX por outro pensador alemão: Carl Schmitt. Entretanto, na sua crítica ao movimento democrático na Europa, Nietzsche já previa que a busca por uma Europa unida não passaria incólume pela produção de líderes totalitários, face o caráter de animal de rebanho do homem moderno. ${ }^{9} \mathrm{~A}$ moral europeia seria uma moral de animal de rebanho, entendida essa como decorrente não do amor ao próximo, de uma bondade divina pregada pelo cristianismo, mas sim pelo temor imposto pela própria comunidade aos seus integrantes por meio da tradição. Um temor ao próximo advindo de tudo aquilo que era considerado nocivo ao rebanho humano, tido como algo mau, face uma espiritualidade castradora dos desejos e impulsos diante de uma mentalidade igualitária medíocre e submissa. O temor seria "o pai da moral" ${ }^{10}$, na filosofia nietzschiana, e nesse sentido, o movimento democrático europeu, como herdeiro do movimento cristão, acabaria promovendo a decadência das organizações políticas por meio de uma mediocrização e rebaixamento do homem, restando aos filósofos a preservação de um espírito forte e original, uma vez que eles seriam os arautos de valores eternos e detentores de uma vontade, porque não dizer, essa sim, soberana.

Imagine-se, comparativamente, a exemplo da Europa e da fragmentada sociedade alemã do século XIX e a atual sociedade latino-americana do qual o povo brasileiro faz parte, a mesma rejeição a um pluralismo político face a multiplicidade de partidos e as múltiplas consequências de ações políticas desastrosas, na condução errática de uma nação, o que levaria agentes do Estado, como os magistrados, a entender semelhantemente que a vontade das maiorias organizadas encontra-se mediocrizada pelo mito da igualdade ou pela ilusão de

\footnotetext{
${ }^{8}$ NIETZSCHE, Estudos sobre o direito, Op.cit. p. 79.

${ }^{9}$ O filósofo é arguto em sua observação acerca da tendência ao assujeitamento do homem europeu, diante de uma Europa pós-napoleônica e pós-revolução industrial, de indivíduos laboriosos sujeitos à escravidão por sua condição econômica de classe e pela mediocrização da política típica da moderna sociedade liberal: “(...) o homem forte, caso singular e de exceção, terá de ser mais forte e rico do que possivelmente jamais foi- graças à ausência de preconceitos em sua educação, graças à enorme diversidade de sua exercitação, dissimulação e arte. Quero dizer que a democratização da Europa é, simultaneamente, uma instituição involuntária para o cultivo de tiranos-tomando a palavra em todo sentido, também no mais espiritual". NIETZCHE, Friedrich. Além do bem e do mal. São Paulo: Companhia das Letras, 2005, p. 135.

${ }^{10}$ Ibid., p. 88.
} 
rebanho, apascentado por meio de lideranças populares demagógicas ou oportunistas? Quão pobre é a moralidade do igualitarismo ou as ilusões promovidas pela visão de uma sociedade moralmente ordeira de irmãos, quando, na verdade, o que prevalece é a força do mais forte sobre o mais fraco. Os contornos de um pensamento político de contornos teológicos em termos da vontade, passa a se desenvolver de forma curiosa até mesmo em autores cristãos, como o católico Schmitt, não obstante um dos maiores apologistas da vontade como Nietzsche, ter sido, em seu tempo, um fervoroso anticristão.

Ora, é justamente na crença na conservação de um povo, como detentor de uma vontade, que se originou na Filosofia do Direito o decisionismo. Este conceito surgiu, seja como movimento político, seja como uma teoria jurídica propriamente dita, na crítica aos desvios da sociedade moderna cujo guardião foi um por vezes titubeante e caótico Estado liberal. Pode-se observar que, tanto na realidade alemã após a I Grande Guerra, quanto no Brasil dos tempos da crise política pós-impeachment, o desenvolvimento de uma vontade que, a cada julgado, destaca-se mais da esfera de moralidade na busca da decisão sobre o certo ou errado, ou do reconhecimento da boa ou da má conduta, é muito mais a busca de se realizar os propósitos da própria vontade do julgador, fundada num poder de decidir. Nesse sentido, o ativismo judicial teria ambiente fértil para se desenvolver. Porém, antes de se observar os contornos desse ativismo, torna-se necessária uma breve análise de seu pressuposto teórico: o decisionismo, e de como tal teoria pode ou não estar vinculada a uma concepção nietzschiana de vontade.

\section{A VONTADE NA TEOLOGIA POLÍTICA DE SCHMITT}

Outro crítico do modelo liberal burguês do Estado e do Direito, e também, em seu tempo, um representante da intelectualidade filosófica germânica, Carl Schmitt irá apresentar algumas considerações sobre a vontade, que apresentam alguns tons de semelhança com a genealogia da justiça e do Estado desenvolvidos na reflexão filosófica de Nietzsche. Enquanto que o último, no século XIX, identificava o poder como o poder de um gênio no meio de um povo, simbolizado pela vontade, o primeiro irá apresentar, no século subsequente, em termos de filosofia prática, uma alusão teológica ou até mesmo sacra da importância do Estado e da manutenção de uma ordem jurídica a ele vinculada, associando vontade com soberania. Entretanto, tanto Nietzsche quanto Schimitt revelam em sua filosofia uma certa carga da cultura germânica, e isto terá implicações significativas, no momento em que toda essa influência cultural resultará numa teoria jurídico-filosófica que será aproveitada pelos julgadores do Direito ocidental, mormente por aqueles de países colonizados, de modernidade tardia como o Brasil.

É bem verdade que, a vontade de que tratava o constitucionalista alemão, referia-se sobretudo a uma vontade soberana, uma vontade que simbolizasse as massas, visto como um corpo homogêneo fundador do Estado e não por meio de partidos ou associações diversificadas, face sua aversão ao pluralismo político e seu desencanto com a democracia representativa ${ }^{11}$ Assim como Nietzsche, Schmitt era refratário ao modelo liberal de contrato social fundado na tese da democracia representativa, trazida pelo lluminismo e pelas

\footnotetext{
${ }^{11}$ BIANCHINI, Fernando Novelli. Democracia representativa sobre a ótica de Schmitt e democracia participativa na apologia de Tocqueville. Campinas: Millenium Editora, 2014, p.50.
} 
O Estado de Direito entre o ativismo judicial e a vontade de poder: uma crítica filosófica à influência decisionista na magistratura, mediante uma reflexão em Nietzsche e Schmitt

revoluções. Sua crença maior, fundada no princípio da identidade, era numa democracia de identidade entre governantes e governados, entre aqueles que mandam e os que obedecem, e, portanto, poderia haver até uma democracia com ditadura, posto que a democracia não se define necessariamente pela liberdade. ${ }^{12}$ Nesse sentido, é curioso observar que, assim como Nietzsche reconhecia no ideal grego: uma unidade de Estado onde senhores e escravos manteriam uma relação natural de dominação, também no Estado moderno schmittiano, o pluralismo da democracia representativa com sua multiplicidade de partidos daria lugar a unidade política.

Para Schmitt, a soberania é exercida pelo Estado, que é quem decide em definitivo sobre as contendas, quem decide em caráter definitivo sobre a ordem e sobre a segurança pública. ${ }^{13}$ Ao se referir ao artigo 48 da Constituição alemã de 1919, Schmitt exortava a norma que dizia que o Presidente do Reich teria a faculdade de declarar o estado de exceção, mas o Reichstag poderia solicitar seu levantamento quando lhe fosse conveniente. A maior atenção que Schmitt dava ao citado dispositivo é que o próprio Estado de Direito propunha uma solução para um estado excepcional: a suspensão total da ordem jurídica vigente ${ }^{14}$. Ora, se o estado de exceção figura como uma alternativa à anarquia e o caos, isso significa dizer que o Estado seria superior à ordem jurídica, subsistindo a ela nesses momentos excepcionais. Tal realidade expressaria a dimensão de massa da soberania, pois afirmaria que aquele que detém o poder, é aquele capaz de decidir sobre a exceção. A vontade de poder estaria, então, corporificada no Estado e seria exercida por meio da decisão. Pela decisão, o Estado suspenderia o próprio Direito a fim de garantir sua própria conservação.

Naturalmente, tal tese sustentada acima deve levar em conta o contexto histórico de crise política e econômica do Estado alemão, entre as décadas de vinte e trinta do século passado, sob a égide da Constituição de Weimar. Naquele tempo, juízes e tribunais eram convidados a solucionar questões que levavam em conta a necessidade de um Estado e governo fortes, sem tibiezas, e que fossem capazes de solucionar os conflitos mesmo quando a interpretação de normas não fosse suficiente para dirimir uma controvérsia. A vontade daquele que pode decidir, mais do que a vontade daquele que decide segundo a norma, parece que passou a se manifestar de forma mais efusiva, não apenas no território alemão há mais de setenta anos, mas, hoje, de forma semelhante, entre os juízes e tribunais brasileiros no atual século XXI. Veja-se, por exemplo, na realidade de crise política nacional, as controvérsias produzidas no meio jurídico, diante da decisão proferida pelo juiz federal Sérgio Moro, da 13a Vara Federal de Curitiba, nos rumos da chamada Operação Lava Jato, acerca da condenação do ex-presidente da república, Luiz Inácio Lula da Silva, nos termos da ação penal no 5046512-94.2016.4.04.7000/PR, em processo por suposto crime de corrupção passiva. Em tal julgado, segundo a crítica de docentes do meio jurídico, como Alexandre Moraes Bahia, Diego Bacha e Silva e Marcelo Cattoni de Oliveira, o que se viu em tal saga judicial foi a apresentação à opinião pública de um lado, de um julgador portador de valores nobres, como honestidade, honradez, coragem e determinação; enquanto que, de outro lado, apresentava-

\footnotetext{
12 Para o jurista de Platemberg, a democracia pressupõe um povo identificado como unidade política. Portanto, a igualdade seria dada não por condições de classe ou vínculo a um determinado grupo, mas sim pela consciência do pertencimento a essa unidade. MACEDO, Ronaldo Porto. Carl Schmitt e a fundamentação do direito. São Paulo: Saraiva, 2011, p. 62.

${ }^{13}$ SCHMITT, Carl. Teologia Política, p. 20.

${ }^{14}$ Ibid., p. 23.
} 
se a figura do réu como sujeito corrompido por vícios mundanos, tais como a cobiça, a simulação, o fingimento ou a desonestidade. ${ }^{15} \mathrm{Na}$ perspectiva no niilismo, a vontade que se apresentou na decisão do julgamento criminal de um ex-mandatário da nação, foi menos a vontade soberana do Estado, por meio de um órgão julgador, do que a expressão da vontade monocrática de um detentor de poder que, por sua condição social e supostas virtudes próprias, estaria acima de qualquer moralidade, inclusive a que norteia o processo penal. Desta forma, ao representar midiaticamente valores, magistrados como Sérgio Moro, na verdade, julgam despidos de quaisquer valores se for aliado ao niilismo um forte componente decisionista, pois a decisão está vinculada ao próprio poder da vontade e não à força de algum valor moral nela embutida. A decisão pela condenação de alguém, levando-se em conta, ou não, as regras do devido processo legal e o princípio da presunção da inocência, deriva da manifestação da vontade sustentada pela autoridade de quem a profere, e não pelos valores que norteariam o que é decidido.

Ainda em relação à vontade de poder e sua base niilista, interessante notar que um dos traços do niilismo como estado psicológico é o postulado da totalidade, sistematização ou organização de todo acontecimento. ${ }^{16} \mathrm{O}$ homem de vontade, no pensamento de Nietzsche, é sequioso de admiração e veneração, e, ao se aproximar do estado de felicidade, sacia-se com a representação de uma suprema forma de governo e domínio. Vinculada a um monismo, a crença numa unidade (assim como pensava Schmitt) passa a ser um dos pressupostos da vontade e que condiciona a decisão. Como está se falando de um mundo sem valores, alheio a qualquer moralidade, busca-se a unidade pelo exercício da vontade, manifestando um poder, para que o homem de vontade encontre na unidade o seu valor. Entretanto, quando o niilismo extingue o devir, conscientizando a vontade de que nada deve ser alcançado e que esta unidade não subsistirá, resta ao homem o subterfúgio de condenar o mundo do devir e inventar outro mundo que para ele é tido como verdadeiro. A última etapa do niilismo seria, por consequência, a descrença num mundo metafísico, no momento em que, ao forjar seu próprio mundo, sua própria unidade, o homem descobre que neste mundo não há valores, mas somente necessidades psicológicas (como para satisfazer seu próprio ego ou egoísmo). Isto implica em dizer que o exercício da vontade, em último caso, quando conduz às visões totalitárias sobre o mundo, acaba por gerar um sentimento de desvaloração, de descrença, onde a medida da descrença é também uma expressão de aumento de poder. ${ }^{17}$

Vontade de poder enquanto vontade de decisão, uma vontade que não passa por imperativos morais. Nisso estaria o cerne do decisionismo como um processo volitivo que cria o Direito e não o contrário. A vontade que subjaz à decisão deriva da autoridade, e é nisso que consiste a soberania do Estado, que, mais que o monopólio da força, detém o monopólio da

\footnotetext{
${ }^{15}$ Afirma-se o exercício de uma vontade de um suposto julgador virtuoso, diante da vontade de resistir a essa vontade moral do réu, nos termos do niilismo nietzchiniano, como um julgamento que transpõe qualquer consideração moral, pois, o juiz da condenação é aquele que julga conforme sua autoridade, por se sentir virtuoso diante do réu e não porque sua decisão é fundada em qualquer corolário da virtude domiciliada em um ordenamento jurídico. MORAES BAHIA, Alexandre Gustavo Melo Franco de, BACHA E SILVA, Diogo, OLIVEIRA, Marcelo Cattoni de. O direito à deriva, o (in) esperado. IN: PRONER, Carol, CITADINO, Giselle, RICOBOM, Gisele, DORNELLES, João Ricardo. Comentários à uma sentença anunciada: o processo Lula. Bauru: Canal 06, 2017, p. 44.

${ }^{16}$ NIEZTSCHE, $A$ vontade de poder, op. cit., p. 32.

17 Ibid., p.34.
} 
O Estado de Direito entre o ativismo judicial e a vontade de poder: uma crítica filosófica à influência decisionista na magistratura, mediante uma reflexão em Nietzsche e Schmitt

decisão. ${ }^{18}$ Segundo Schmitt: "a autoridade demonstra que para criar o direito não necessita haver direito". A decisão nasce de um nada normativo, e, assim, Schmitt tributa como precursores filosóficos do decisionismo Jean Bodin e Thomas Hobbes, sendo que este último é quem teria melhor sistematizado uma ideia de autoridade como princípio, início absoluto, uma arché que se manifesta quando a desordem dá lugar à ordem por meio da decisão. Por isso que o soberano pode se apresentar, inclusive, sob a forma de um ditador, pois é o ditador quem acaba com a desordem da bellum omnium contra omnes. ${ }^{19}$

Será, portanto, que diante de uma crise de legitimidade do Estado liberal, afetada pela perda de credibilidade de seus representantes encastelados nos partidos, face o pluralismo político, pode, numa democracia, o juiz funcionar como um ditador ou comissário? Se for entendida a decisão como produto da autoridade e compreensão desta como detentora de uma vontade que pode decidir, está construído o engenhoso mecanismo decisionista que dará ensejo a todo um ativismo judicial, onde juízes, por meio da vontade, agiriam como órgãos jurisdicionais na perspectiva da ação daquele que pode decidir porque quer decidir, e não porque é moral ou legalmente obrigado a isso. Desta forma, pode-se afirmar que a discricionariedade judicial, fecundada pelo positivismo jurídico, acabou por colher seus maiores frutos no decisionismo, no momento em que mais e mais juízes passaram a sentir uma maior atração pela exceção do que pela normalidade da regra ${ }^{20}$. Decidir numa ordem jurídica sobre garantias atinentes ao devido processo legal, enquanto princípio constitucional associado à manutenção de liberdades ou garantias, como a racionalidade sobre o uso de algemas de réus e condenados presos, a condução coercitiva de suspeitos e testemunhas em processos criminais e a execução de penas de réus condenados em segunda instância, passa a ser tratada pelo olhar das exceções e não pelo parâmetro das regras jurídicas existentes, dentro da normalidade de uma ordem jurídica, pois o mais importante não é essa ordem propriamente dita, mas sim o poder de decidir.

\section{OS JUÍZES-LEGISLADORES EM TEMPOS DE EXERCÍCIO DE UMA VONTADE DE DECISÃO}

Chega-se a um ponto de discussão deveras instigante acerca da atuação jurisdicional brasileira. No debate entre Lênio Streck e Álvaro de Souza $\mathrm{Cruz}^{21}$ sobre a importância ou não do controle difuso da constitucionalidade, tendo em vista a crítica do primeiro às teses habermasianas, e a defesa pelo segundo de um modelo de constituição aberta, típica do pensamento de Häberle, parece-se encerrar um controvertido diálogo sobre o papel da magistratura numa democracia. Afinal de contas, conferir ao juiz o papel de um intérprete

\footnotetext{
${ }^{18}$ SCHMITT, Teologia política. Op. Cit., p. 25.

${ }^{19}$ MACEDO Jr. Op.cit.,p.48.

${ }^{20}$ Schmitt debate filosoficamente sobre o fascínio da exceção na doutrina de Locke e no racionalismo do século XVIII até Kant, quando afirma que "a exceção é mais interessante que o caso normal”. Nesse sentido, a exceção funcionaria como um filtro da realidade, quebrando a casca da aparência das repetições da normalidade. SCHMITT, Teologia política, Op. Cit., p. 27.

${ }^{21}$ Uma das discussões fulcrais do debate é se Habermas teria ou não se afastado da razão prática kantiana, que, na crítica de Nietzsche, padece de fundamentação quanto à justificação da vontade, já que se trata de uma matriz filosófica fundada na moralidade, e deveria ser o componente moral o elemento kantiano que levaria, por fim, à decisão. SOUZA CRUZ, Álvaro de. Hermenêutica jurídica em debate. Belo Horizonte: Editora Fórum, 2007, p. 155.
} 
que julga conforme sua vontade e não conforme a norma, parece ser o nexo que aproxima o decisionismo do ativismo judicial.

Para Streck, a questão da interpretação ou da decisão sobre a forma de sentença, enquanto expressões de uma vontade, não deixa de atravessar diversos campos ideológicos do Direito. Por exemplo, na sua crítica ao conteúdo decisionista do pensamento de juristas como o penalista baiano Paulo Queiroz, quando este, por sua vez, afirma que condenação ou absolvição não são atos de verdade, mas sim atos de vontade, Streck faz alusão a Nietzsche, ao falar do solipsismo judicial, afirmando que, assim como o ceticismo nietzchiniano preconizava uma vontade que decide porque quer a decisão conforme sua própria realidade, e não porque interpreta conforme uma dada realidade, o reducionismo interpretativo decisionista conduziria o julgador a uma não compreensão do mundo. ${ }^{22} \mathrm{O}$ solipsismo decisionista ignora a compreensão pois desta não necessita, já que é fundado na vontade, que formula suas próprias realidades. Desta forma, é contemporâneo se dizer que as últimas e polêmicas decisões proferidas no âmbito da Operação Lava Jato, mormente no que diz respeito à condenação criminal de um ex-presidente, fato inédito e notoriamente controverso no período recente da história republicana, carregam em si um forte conteúdo decisionista, calcada na vontade do julgador, impelido por um ativismo judicial, do que pelo mero exercício da jurisdição, nos termos de sua previsão constitucional.

Obviamente, decisionismo e ativismo judicial não são expressões sinônimas, e, não necessariamente, um decorre do outro. Entretanto, é por meio do ativismo que o decisionismo estende seus desdobramentos. Nos sistemas jurídicos britânico e estadunidense o ativismo surge da possibilidade da função jurisdicional concorrer com a função legislativa na produção de normas jurídicas futuras ${ }^{23}$. Além de disciplinar situações futuras por meio dos precedentes, os tribunais desses sistemas estrangeiros, distintos do sistema romanista, também podem rever esses precedentes, revogando-os. Trata-se do exercício puro da vontade do julgador diante de situações imediatas e concretas, bem como perante hipóteses futuras de casos in abstrato. Ocorre, portanto, uma vinculação da lei à decisão, e não o contrário, como é comumente ensinado na teoria jurídica pátria, em conformidade a uma tradição do positivismo jurídico no seu culto à lei. Por vezes o ativismo de alguns juízes e tribunais é elogiado por conta de sua intrepidez ao desafiar, por meio da abertura interpretativa, as restrições de alguns textos legais, decidindo conforme supostas exigências sociais (ou até mesmo midiáticas) da conjuntura política, diante da passividade do legislador perante determinadas condutas. ${ }^{24}$ Isto funciona principalmente em matérias de conteúdo penal, onde, recentemente, determinadas decisões sobre a condução coercitiva, mereceram destaque e sua posterior reprimenda por meio de decisão proferida, em sede de liminar, no Supremo Tribunal Federal, por voto do ministro Gillmar Mendes, nos termos de uma ação de arguição de descumprimento de preceito fundamental, promovida pela Ordem dos Advogados do Brasil, onde se questionava o uso indiscriminado de tal medida processual em

\footnotetext{
${ }^{22}$ STRECK, Lenio Luiz. O que é isto? Decido conforme a minha consciência. Porto Alegre: Livraria do Advogado, 2013, n.p.).

${ }^{23}$ A influência do common law e do direito norte-americano parece ter influenciado alguns magistrados brasileiros, mormente após o desenvolvimento de institutos como a delação premiada, onde é permitida toda uma margem de discricionariedade ao julgador a fim de julgar determinadas situações, abrindo precedentes em seus julgados para decisões futuras por outros órgãos jurisdicionais. RAMOS, Elival da. Ativismo judicial. São Paulo: Saraiva, 2015, p. 109.

24 Ibid., p. 112.
} 
O Estado de Direito entre o ativismo judicial e a vontade de poder: uma crítica filosófica à influência decisionista na magistratura, mediante uma reflexão em Nietzsche e Schmitt

ações penais, a constranger a liberdade de réus, testemunhas e até mesmo de meros suspeitos, em grandes investigações. ${ }^{25}$ Mediante tais controvérsias, observadas no meio judicial brasileiro, não há como não se cogitar de uma forte influência decisionista no desenvolvimento do ativismo judicial pátrio, fundado, sobretudo, numa vontade de poder.

Para Nietzsche, tal vontade parecia ser odiada nos períodos democráticos, pois seria identificada com a vontade egoísta do dominador ou tirano. ${ }^{26}$ Ora, citando Helvétius, Nietzsche defende a proposição de que as pessoas aspiram o poder a fim de obter prazeres, e a obtenção de poder, portanto, traria a felicidade. Como o Estado é uma representação das classes dominantes, naturalmente elas perseguirão o poder através do ente estatal e a vontade será o exercício da vontade do poderoso. Nas diferentes formas de governo e sistemas políticos isso pode ser visto pelo exemplo da realeza, que representa a ambição de poder de um salvador, de um semideus; da aristocracia, que representa a fé no poder de uma elite, de uma casta superior iluminada; e, finalmente, tem-se na democracia a descrença nos grandes homens e na elite, pois é o poder da plebe que se manifesta, acreditando no exercício do seu próprio poder. O que dizer então de um Estado ou sistema político onde os magistrados se sentem os reais atores do poder? Vê-se, portanto, na obra de Nietzsche, que suas concepções sobre a Justiça e o Direito, menos do que apegadas a um positivismo jurídico face o vínculo dessa corrente teórica à discricionariedade judicial, estão mais voltados para o Direito enquanto uma versão jusnaturalista das relações humanas, como relações naturais de troca e força, donde a vingança faz parte da esfera da justiça. ${ }^{27}$

É na concepção da justiça enquanto troca na relação de forças entre vontades, que irá se abrir o caminho para o decisionismo judicial e para um ativismo, onde o Judiciário passa a aparentar mais protagonismo diante do debate político patrocinado pelo Estado por meio de decisões judiciais. Na relação entre fortes e fracos há direitos, respectivamente, maiores e menores, e a moralidade terá muito maior relação com a tradição, na definição do que é "bom" ou "mal" do que na própria legalidade enquanto manifestação do Direito estatal. Alega-se que, por meio dessa vontade de decisão, buscam-se decisões justas para reprimir condutas más, definidas desta forma por serem consideradas boas ou ruins conforme a opinião da elite ou da plebe. Entretanto, decisões judiciais proferidas nos últimos anos no Brasil, de intensa repercussão midiática, face os atores políticos envolvidos em processos penais para apuração de crimes de corrupção, parecem demonstrar muito mais um apego à tradição, na afirmação de juízes de que se estaria, por meios destes julgados, construindo um país melhor e mais ético, quando estas decisões, na verdade, reproduzem tão somente a disposição natural de se fazer justiça com vias a satisfazer os interesses egoístas daqueles que efetivamente exercem o poder, pois são dotados de força para isso.

As recentes decisões judiciais proferidas tanto em primeira instância quanto no segundo grau de jurisdição, que, de alguma forma, atingem os alicerces do edifício político, ao intervir no próprio sistema eleitoral e afetar o debate democrático por meio de liminares e sentenças condenatórias, retirando de cena seus protagonistas ou atores habilitados a participar do debate democrático, também representam um âmbito discricionário de tomada

\footnotetext{
${ }^{25}$ BRASIL, Supremo Tribunal Federal. Arguição de descumprimento de preceito fundamental nํ444. Requerente: Ordem dos Advogados do Brasil. Impetrado: Presidente da República. Relator: Ministro Gilmar Mendes. Brasília18 de dezembro de 2017. Disponível em: https://www.conjur.com.br/dl/adpf-444-conducaocoercitiva.pdf. Acesso em 08 janeiro 2018.

${ }^{26}$ NIETZSCHE, A vontade de poder. Op. Cit., p. 376.

${ }^{27}$ NIETZSCHE, Escritos sobre o direito, Op. Cit., p.77.
} 
de decisões que nada ou pouco tem a ver com moralidade. Menos do que o exercício do resgate de uma moralidade sobre o pretenso jargão do combate à corrupção em sede de ações penais, muitas das decisões proferidas em senda criminal têm o condão de tão somente exercerem um poder político, expressando muito mais uma vontade que, subjaz na vontade do julgador de suplantar a vontade do ato político ao exercer sua potência transformadora, assumindo até mesmo a função do poder legiferante. Desta forma, no ativismo da magistratura, juízes assumem o lugar dos legisladores, demolindo o mito da supremacia parlamentar da democracia representativa do Estado liberal, colocando em seu lugar um Estado de unidade política, numa ditadura de comissariado schmittiana, onde os comissários são os reais detentores do poder, e assim como os militares, em tempos pretéritos da República, agora demonstram aqueles que julgam o desejo do exercício do poder, produzindo o Direito, no lugar dos representantes legislativos, vistos com suspeição por conta de sua suposta inércia ou comprometimento com os inimigos, situados no outro lado do embate político. ${ }^{28}$ Uma república de amigos dos juízes ou inimigos dos juízes não passa, necessariamente, por uma distinção moral entre bons e maus, uma vez que a dicotomia política acima assinalada não necessita de balizas morais para se consolidar. O embate amigo $\mathrm{X}$ inimigo trata-se, sobretudo, de uma relação de troca nas relações de força, onde cada um exerce sua vontade na perspectiva de afirmação de um poder, até que o veredito final seja dado pelo vencedor; ou seja, por aquele quem profere a sentença. Desta forma, percebe-se nitidamente por meio da reflexão político-filosófica, que, paulatinamente, na República brasileira, os juízes vão se tornando os reais atores do poder.

Essa usurpação, por vezes, silenciosa do poder, é calcada numa vontade que, menos do que soberana, exorta uma vontade acima de qualquer moralidade, além do bem e do mal, por ser tão somente exercício de poder. A vontade de decisão configura-se nos moldes de um ativismo que tem suas raízes no século $X X$ no ceticismo interpretativo, típico do positivismo e do realismo jurídico, o que levam, por sua vez, a tomadas de posições decisionistas. ${ }^{29} \mathrm{Afinal}$, na história dos embates judiciais, a discussão sobre aquilo o que decidir e sobre porque decidir levou em conta muito mais existências pragmáticas ditadas pelos fatos, do que propriamente uma reflexão sobre as normas. Nesse sentido, ao dispensar a interpretação em prol da vontade, a sabedoria para a decisão sobre o que define um réu como culpado ou inocente, uma conduta como típica ou atípica do ponto de vista de uma norma penal incriminadora, e mesmo se um réu é merecedor de certas garantias, como a presunção da inocência, não é mais encontrada num cabedal normativo, mas sim na própria vontade solipsista do julgador. Decide-se porque se deve decidir e tão somente por isso. Decide-se por que a realidade dos fatos leva o juiz a agir.

Neste ativismo, de certa forma, a figura da casta de soldados invocada por Nietzsche assemelhar-se-ia com a casta de juízes em plena atividade judicante de intervenção no ambiente político, convertida numa ação entre amigos contra inimigos, na representação de uma casta de soldados togados, confiantes no exercício da vontade, assim como as ordens militares já desenvolveram em relação aos inimigos do Estado, em momentos históricos pretéritos.

\footnotetext{
${ }^{28}$ Todo debate político passa a ser concebido como um embate entre categorias distintas, que se confrontam no reconhecimento do outro, sem que tais aproximações ou distanciamentos se deem num âmbito de moralidade entre bons e maus. SCHMITT, Carl. O conceito do político. Rio de Janeiro: Vozes, 1992 p. 52.

${ }^{29}$ RAMOS, Elival da Silva. Op.Cit.,p. 75.
} 
O Estado de Direito entre o ativismo judicial e a vontade de poder: uma crítica filosófica à influência decisionista na magistratura, mediante uma reflexão em Nietzsche e Schmitt

Menos do que o Estado em sua totalidade, o führer agora se vê simbolizado na figura do juiz ou do órgão julgador. Cabe a ele a defesa da Constituição ${ }^{30}$, sendo que ocorre na realidade brasileira um fato curioso: os próprios magistrados individualmente considerados passam a assumir para si o protagonismo no lugar dos tribunais. Em outras palavras, parece que o gênio criativo a que se referia Nietzsche, como detentor da vontade, agora se resume ao personagem do juiz de primeira instância ou ao membro isolado de um tribunal cujo voto destoa de seus pares, que, diferentemente do magistrado apolítico, neutro, juridicamente puro, criticado por Schmitt, assume um protagonismo político direto na discussão de questões constitucionais que interferem na lógica de poder do Estado.

Desta forma, questões sobre elegibilidade de mandatários, a possibilidade ou não de membros do Congresso Nacional serem processados, a prisão ou não de chefes políticos e a continuidade de seus mandatos ou a possibilidade de se eleger .e até a faculdade assegurada constitucionalmente ao chefe do poder executivo de nomear ministros de Estado, parecem agora não mais questões a serem solucionadas no espaço interno do sistema político, mas sim em seu entorno jurídico, por meio da transformação dessas questões em questões judicializáveis, por obra do exercício de uma vontade de decisão. Nisso, esvai-se até mesmo o espaço de poder do legislador e dos atores políticos propriamente ditos, assumindo o espaço da vontade não mais o titular dos interesses populares, nos moldes da democracia representativa, mas sim o julgador, o magistrado, que dispõe, por meio do ativismo, de um amplo leque de possibilidades de intervenção no debate democrático, definindo por si o cronograma de lutas políticas, à revelia de seus principais atores, leia-se: o povo organizado e real titular da soberania num Estado democrático.

$\mathrm{O}$ ativismo deixa, portanto, marcas no tecido constitucional brasileiro. Suas bases filosóficas não podem ser relegadas simplesmente ao decisionismo propiciado pela discricionariedade, se o seu elemento central focado na vontade for olvidado. Trata-se de uma vontade de decisão consubstanciada em um querer, numa vontade de exercitar um poder movido pelo prazer da dominação, pela dinâmica daqueles que decidem porque podem decidir. Nesse sentido, soçobra o edifício democrático trazido pelo modelo do Estado liberal parlamentar, entrando em descrédito os representantes parlamentares pela ação diuturna de juízes ativistas.

\section{- CONCLUSÃO}

É de se observar que nas discussões trazidas ao Brasil por meio do neoconstitucionalismo no século passado, muito das aspirações schmittianas não passaram incólumes ao crivo hermenêutico dos julgadores pátrios. O germanismo constitucional presente na formação jurídica brasileira dos publicistas, ao menos na segunda metade do século passado, trouxe consigo não somente um forte sotaque decisionista, mas também uma influência niilista que tem seus precedentes na filosofia de Nietzsche que não poderia passar despercebida, após arguta análise filosófica.

O decisionismo aproxima-se do niilismo enquanto que a crença numa vontade que decide também é a crença na unidade, numa unidade política forjada na mente do próprio

${ }^{30}$ MACEDO JUNIOR, Op. Cit.,p.71. 
julgador para sua satisfação individual, e não num sistema de valores de conteúdo moral. A visão totalitária de mundo desvela-se numa concepção em que o decidir sobre a exceção implica, necessariamente, à construção de um novo mundo, desvalorado; onde a perfeição do sistema é a perfeição desejada tão somente pela vontade. Oposições democráticas fundadas no pluralismo não teriam vez diante do monismo centrado numa realidade política adquirida com a decisão. A visão do Estado enquanto uma entidade guerreira, onde seus agentes são investidos de força e dela podem se valer para solucionar os conflitos, consolidam uma crença na decisão mais forte do que na própria legalidade como fundamento do direito.

Como é oriunda de um nada normativo, a decisão constitui-se numa entidade que incorpora o espírito do gênio invocado por Nietzsche, a sustentar o magistrado enquanto um guerreiro, um soldado a representar o fim último do Estado, qual seja o da manifestação da força. Trata-se de uma força aplicada na perspectiva de construção de uma igualdade na formação de uma unidade política a partir da distinção entre amigos e inimigos, conforme alude a teoria de Schmitt. Tal unidade repele o pluralismo político típico do modelo de democracia representativa do Estado liberal, face descrédito com o sistema erigido por seus representantes. Importa salientar que, no atual momento de crise ética e de representatividade pela qual passa o Estado brasileiro, com muitos de seus personagens, dentre parlamentares e lideranças políticas, sofrendo condenações criminais ou sendo acusados em processos judiciais, e, muitas vezes, enfrentando a prisão, vê-se que os mandatários da democracia representativa são paulatinamente desabilitados como atores políticos no debate democrático, não por meio da decisão popular por meio do voto, mas sim por meio de sentenças condenatórias ou liminares.

O ativismo judicial surge, portanto, como uma resultante sócio-político do desenvolvimento de uma vontade de decisão no cerne da magistratura brasileira. Isso proporciona fenômenos de proporção considerável, como uma tendência crescente à judicialização da política, observável por meio de flagrantes incertezas quanto os rumos do processo político, comprometendo, até mesmo, o cenário eleitoral, quando não as próprias perspectivas de cumprimento de normas constitucionais quanto à concretização de direitos políticos fundamentais.

As considerações sobre a vontade, seja enquanto vontade de poder ou sob a forma de uma vontade de decisão, tratam da própria manutenção ou não de um Estado Democrático de Direito, levando-se em conta que se opera, ao menos em termos corporativos, no seio da magistratura certo movimento no sentido de firmar os juízes como verdadeiros protagonistas na luta política no Brasil, o que se torna demasiadamente temerário ao culminar na formação de uma suposta democracia de comissariado, face ser povo, detentor de diversas vontades, o real agente político soberano.

\section{REFERÊNCIAS}

BIANCHINI, Fernando Novelli. Democracia representativa sobre a ótica de Schmitt e democracia participativa na apologia de Tocqueville. Campinas: Millenium, 2014.

GIACOIA JUNIOR, Oswaldo. Nietzsche $X$ Kant: uma disputa permanente a respeito de liberdade, autonomia e dever. Rio de Janeiro: Casa da Palavra, 2012. 
O Estado de Direito entre o ativismo judicial e a vontade de poder: uma crítica filosófica à influência decisionista na magistratura, mediante uma reflexão em Nietzsche e Schmitt

MACEDO Jr., Ronaldo Porto. Carl Schmitt e a fundamentação do direito. São Paulo: Saraiva, 2011.

MORAES BAHIA, Alexandre Gustavo Melo Franco de, BACHA E SILVA, Diogo, OLIVEIRA, Marcelo Cattoni de. O direito à deriva, o (in) esperado. IN: PRONER, Carol, CITADINO, Giselle, RICOBOM, Gisele, DORNELLES, João Ricardo. Comentários à uma sentença anunciada: o processo Lula. Bauru: Canal 06, 2017

NIETZSCHE, Friedrich Willhem. A vontade de poder. Tradução Marcos Sinésio Pereira Fernandes, Francisco José Dias de Moraes. Rio de Janeiro: Contraponto, 2008.

, Além do bem e do mal. Tradução Paulo César de Souza. São Paulo: Companhia das Letras, 2005

Escritos sobre o direito. Tradução Noéli Correia de Melo Sobrinho. São Paulo: Ed. Loyola, 2009.

SCHMITT, Carl. Teologia política: cuatro ensayos sobre la soberania. Buenos Aires: Editorial Struhart e cia, 1998.

. O conceito do político. Tradução Álvaro Valls. Petrópolis: Vozes, 1992.

RAMOS, Elival da Silva. Ativismo judicial: parâmetros dogmáticos. São Paulo: Saraiva, 2015.

SOUZA CRUZ, Álvaro Ricardo de. Hermenêutica jurídica em debate: o constitucionalismo brasileiro entre a teoria do discurso e a ontologia existencial. Belo Horizonte: Fórum, 2007.

STRECK, Lenio. O que é isto? Decido conforme a minha consciência. Porto Alegre: Livraria do Advogado,2013. 